\title{
Design and simulation of 20MW photovoltaic power plant using PVSyst
}

\author{
Ashish Grover ${ }^{1}$, Anita Khosla ${ }^{2}$, Dheeraj Joshi ${ }^{3}$ \\ ${ }^{1,2}$ Deprtment of Electrical \& Electronics Engineering, Manav Rachna International Institute of Research \& Studies, India \\ ${ }^{3}$ Department of Electrical Engineering, Delhi Technological University, India
}

\begin{tabular}{l} 
Article Info \\
\hline Article history: \\
Received Aug 8, 2019 \\
Revised Dec 12, 2019 \\
Accepted Jan 2, 2020 \\
\hline Keywords: \\
Grid \\
Irradiance \\
Photovoltaic \\
PV Array \\
PV syst \\
\hline
\end{tabular}

\begin{abstract}
This paper deeply explains the analysis through simulation and sizing of grid connected photovoltaic plant of 20MW for the site Devdurga, Karnataka India with use of PV syst software tool. Primarily, the trajectories obtained from the software describes performance of PV configuration at a particular location. It gives results for the geographical position taken by maps for sizing of the components which projects the installation with very much realistic conditions. The projected area is of about 110 acres would generate 44854 $\mathrm{MWh} /$ year for a $20 \mathrm{MW} \mathrm{PV}$ configuration, with a performance ratio of $76.28 \%$.Loss fraction taken for simulation and sizing is $2 \%$. The paper also includes the study and behavior of the system with tilt and orientation of the PV Panel which gives better simulation results at similar latitudes for any feasible sizing.
\end{abstract}

Copyright $(2020$ Institute of Advanced Engineering and Science. All rights reserved.

\section{Corresponding Author:}

Ashish Grover,

Department Electrical \& Electronics Engineering,

Manav Rachna International Institute of Research \& Studies,

Faridabad, Haryana, India.

Email: ashi.21s@gmail.com

\section{INTRODUCTION}

India is one of the few countries with an annual GDP growth of above 4.5\%. The GDP of the country is positively correlated with electricity demand. Until now, the major contributors of electricity generation were fossil fuels in India. Now India is keen to consider fuel substitution from the point of view of energy security. The "National Action Plan on Climate Change" is one of the major initiatives by the Government of India with 8 National Missions one of which is the Jawaharlal Nehru National Solar Mission [1]. The mission has been set with a target of achieving grid-connected solar power capacity of $1000 \mathrm{MW}$ by the year 2013, 10000 MW by 2017 and 20000 MW by 2022. The enforcement of Renewable Purchase Obligations and the growth of the Renewable Energy Certificate market are also likely to fuel a rapid expansion in the installation of solar power plants. The demand for energy, shortfall of its availability and the increased focus on renewable energy sources like the sun encourage the installation of solar photovoltaic power plants to generate green energy. It is not only a need of the hour but also a good investment for the future [2].

\subsection{Solar power scenario in India}

India is enriched with inexhaustible solar energy potential, which is equipped for delivering 5,000 trillion kilowatts of clean Power. Nation is honored with around 300 bright days in a year and Sun isolation of 4-7 kWh per sq. m every day [3]. This energy is saddled effectively, it may use to reduce energy deficiency as per present demand and that is without harmful gases. Numerous States in India have effectively perceived and recognized solar energy generation and other are arranged to meet their developing energy needs with long lasting solar power. 


\section{GRID-TIED PV SYSTEM SIZING}

Grid connected PV systems are becoming popular because of their applications in distributed power generation and efficient of PV array power. To optimize the system sizing of the components is required and to achieve the same proper space, climatic conditions and power is the main objective. The Figure 1 of the grid connected system has two stages of conversion, one is to process PV Power and secondly to feed into the grid. In this stage the increase voltage will track the maximum power. And in the Second stage AC power of improved quality will be inverted from DC Power [4-5].

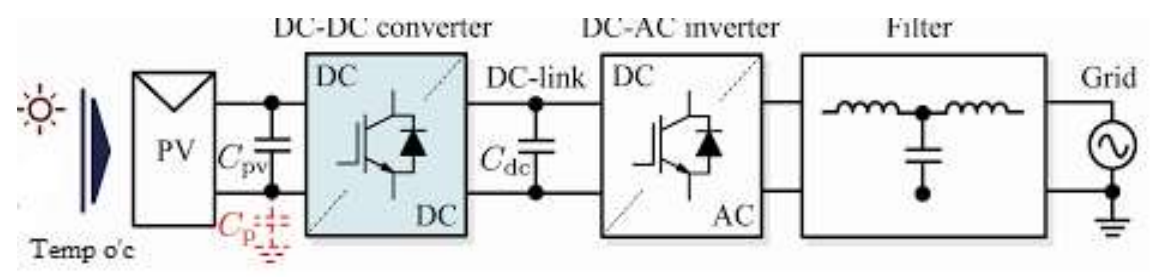

Figure 1. Block Diagram of PV Grid connected Power Plant

\subsection{Components}

The PV module is the group of PV cells combined together in series and parallel. Depending on the availability at the time of the project and the site suitability, any one of the following types of the modules could be deployed for the project. There are two major types of the solar cell technologies in Figure 2 available in the market on commercial basis. These are crystalline solar cells and Thin-film solar cells [6].

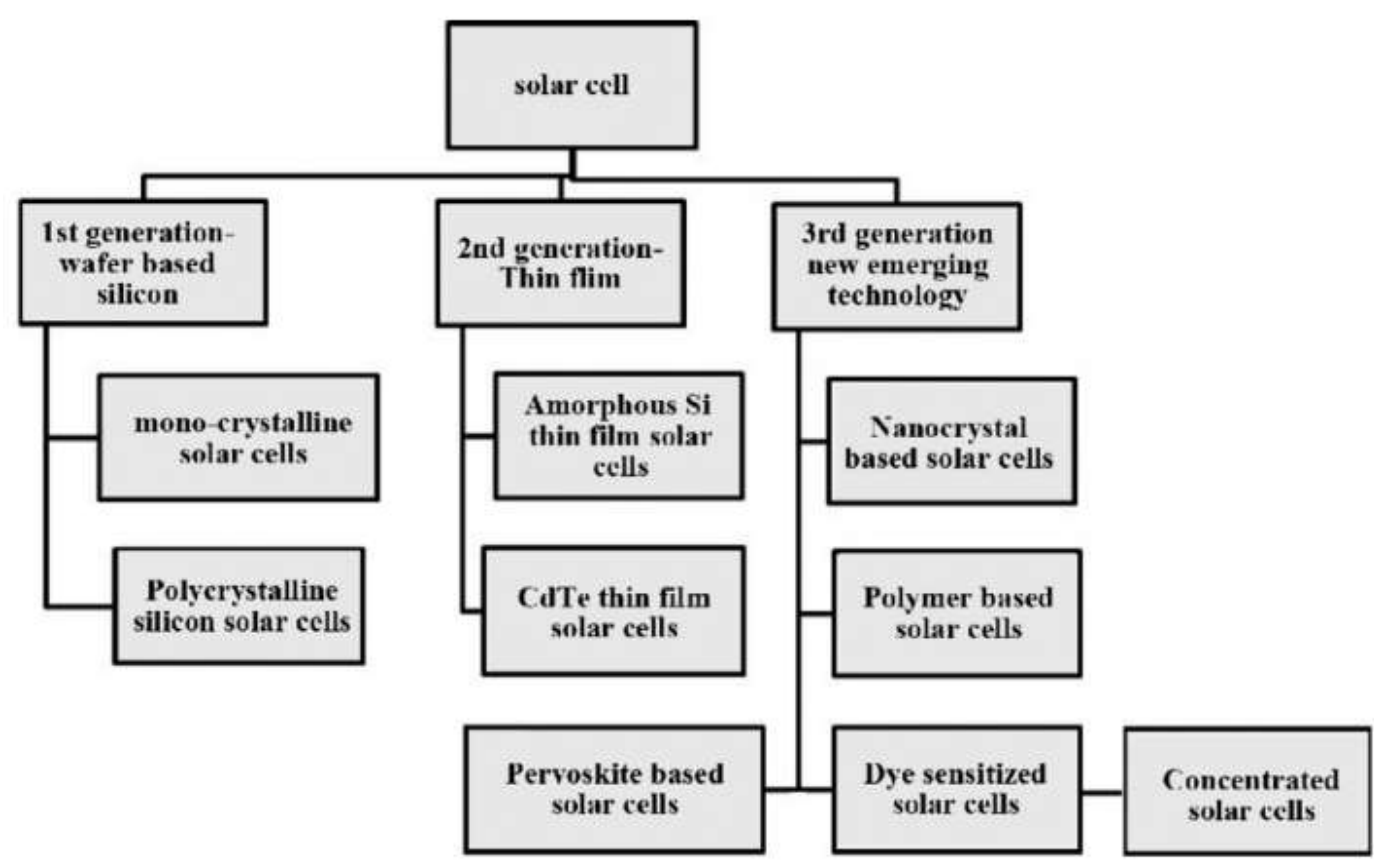

Figure 2. Solar Cell Technologies

The 20 MW Solar PV plant will use Crystalline with single axis (E-W) tracker [7]. The standard technical arrangement of $20 \mathrm{MW}$ solar projects mentioned in Table 1. The PV modules will be electrically connected in series with UV Resistant copper cables with proper size to get minimum DC losses. The production obtained from PV modules will be provided by cables to string monitoring boxes, where current of each string will be monitored for operation and maintenance of the plant. The inverters are connected to string monitoring boxes, which will convert the DC Power of $380 \mathrm{~V}$ into alternating power [8]. Each of this 
structure can support 21 modules. The structure is made of galvanized steel profiles and is inclined $(-45$ to +45$)$ deg to horizontal. PV modules are directly mounted on the module support members. The aluminium frame of each solar module is galvanic ally isolated from the steel supporting beam to prevent localized corrosion and high quality stainless steel fixings are used throughout [9].

Table 1.Parameters of 20 MW PV Power Plant

\begin{tabular}{cc}
\hline \multicolumn{2}{c}{ Summary of 20 MW Solar PV Power Plant } \\
\hline Nominal location & $16^{\circ} 18^{\prime} 9.00 " \mathrm{~N} ; 76^{\circ} 50^{\prime} 40.00^{\prime \prime} \mathrm{E}$ \\
PV module & Multi crystalline \\
Inverters & $1000 \mathrm{~kW}$ \\
Inverter power(kW) & $1000 \mathrm{KW}$ \\
Inverters per plant & 20 \\
Power of plant(MW) AC & $20 \mathrm{MW}$ \\
Plant DC:AC ratio & 1.12 \\
\hline
\end{tabular}

\subsection{Inverter selection}

In solar system, power is conditioned through a control circuit which consists of inverter. The other control devices used in grid-connected solar structure are maximum power point tracker (MPPT), synchronization and remote controlling electronic devices. The main functions carried out by control circuit are:

a) The inverter converts DC supply generated from PV modules in AC supply. The generated power has less harmonic distortions for better efficiency [10].

b) The inverter also behave as protective device which will trip the circuit if the voltage, current or frequency are not within acceptable ranges.

c) On the basis of PV module selected, required inverter is of rating such that it will generate power of $1000 \mathrm{~kW}$ at voltage level 110 Volts DC [11].

\subsection{Installation location}

The metropolitan area of Devdurga, Karnataka has been taken as site location of the grid-tied solar photovoltaic installation with geographical coordinates: $16^{\circ} 18^{\prime} 9.00^{\prime \prime} \mathrm{N} ; 76^{\circ} 50^{\prime} 40.00^{\prime \prime} \mathrm{E}$.

\subsection{Irradiance in PV module}

The irradiance data for the site which includes irradiance, temperature, wind speed etc has been downloaded from NASA. The Table 2 shown give details of the site [12-13].

Table 2. Yearly Range of Solar radiations and air Temperature

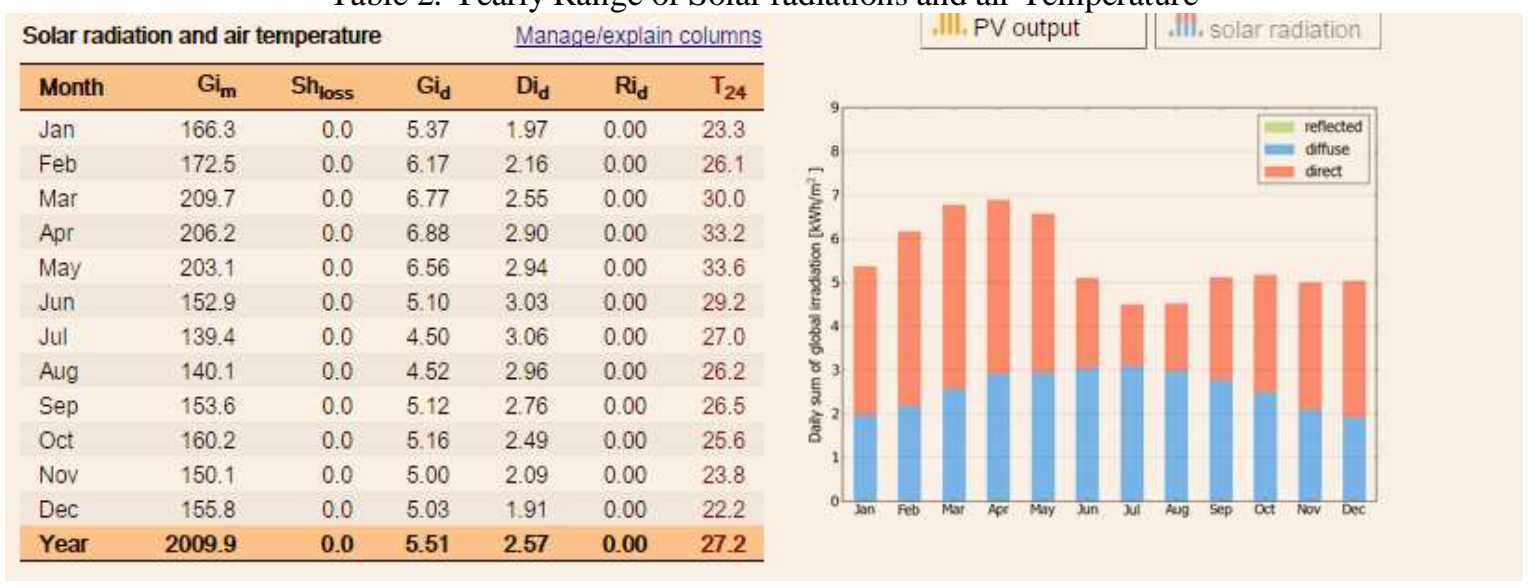

\section{SIMULATION USING PVSYST SOFTWARE}

The PV performance for the sizing of units is mainly done with help of PV syst. The experiment results may be calculated on hourly based generation which will be performed for the year. The performance of the system may be tracked for the yearly generation and then arrangement of the system will be obtained with desired environmental conditions, temperature and speed for the maximum power output. The software 
has inbuilt database of irradiance values for different regions of the world along with various components of PV system to design a plant. PVsyst designs the system in different stages. Firstly by the PV syst, approximate dimensions for the system will be obtained and also the size of the components to be applied. It will provide pre-sized production of the system [14].

The design stage of the project provides detailed simulation results of system by taking the photovoltaic components values on hourly basis. The next stage is database, the irradiance data may be entered from external source either manually or automatically for the location selected from NASA SEE RET screen [15-16] .The software imports the meteorological information only by entering geographical coordinates. Further, the software has vast library for database of climatic conditions, components, analysis and behavior of measured data for Photovoltaic systems. Below, represents the actual simulation results on Devdurga site for photovoltaic grid connected system [17].

\subsection{Trajectories of $\mathbf{P V}$ modules}

Figure 3 shows the movement of the sun based on deteriorated trajectories at different angles. The figure shows the incidence solar rays on PV modules which depends on the tilt and azimuth values [18]. Figure 3-6 shows the performance results of $20 \mathrm{MW}$ Grid connected solar power plant.

\subsection{Results and findings}

After Simulation, PVsyst gives us the following results:

1) Energy Output: The energy produced is $41854 \mathrm{MWh} /$ year in Figure 7 and a performance ratio (PR) of 76.28 $\%$ at $50{ }^{\circ} \mathrm{C}$ as operating temperature PV modules. The results shows that maximum energy is produced in the month of March $4291 \mathrm{MWh}$ and minimum energy is produced in the month of July [19-20].

2) Balances and main outputs: Yearly horizontal radiations coming on solar panels is $2000 \mathrm{Kwh} / \mathrm{m} 2$. Annually global energy focusing on collector is $2450 \mathrm{KWH} / \mathrm{m} 2$. Output energy received from the PV array is 44052 annually.

3) The annual efficiency [21] of rough area obtained for PV array i:e Eout/Array is $13.25 \%$ and for whole system Eout/System is $12.59 \%$.

4) Normalized Energy Outputs values: The loss value inverter side, LC is recorded as $1.32 \mathrm{~kW} \mathrm{h/kW} \mathrm{p/day}$ and the loss value of system, LS is $0.27 \mathrm{~kW} \mathrm{h/kW} \mathrm{p/day} \mathrm{and} \mathrm{inverter} \mathrm{energy} \mathrm{output} \mathrm{is} \mathrm{given} \mathrm{as} \mathrm{YF} \mathrm{is} 5.12$ $\mathrm{kW} \mathrm{h/kW} \mathrm{p/day} \mathrm{[22].}$

5) Loss Diagram: The value of global horizontal irradiance is $2000 \mathrm{~kW} \mathrm{h/m2} \mathrm{[23].} \mathrm{The} \mathrm{effective} \mathrm{irradiation}$ on the collector plane is $2286 \mathrm{~kW} \mathrm{~h} / \mathrm{m} 2$. The values shows that total loss energy is $0.2 \%$. The energy conversion of solar radiations into electrical energy, so total energy generated by PV array is $51203 \mathrm{MWh}$ shown in Figure 8 and the efficiency at standard test condition is $16.56 \%$. The available array virtual energy is 44052 and the available energy to inverter output is $43272 \mathrm{MWh}$ [24-25].

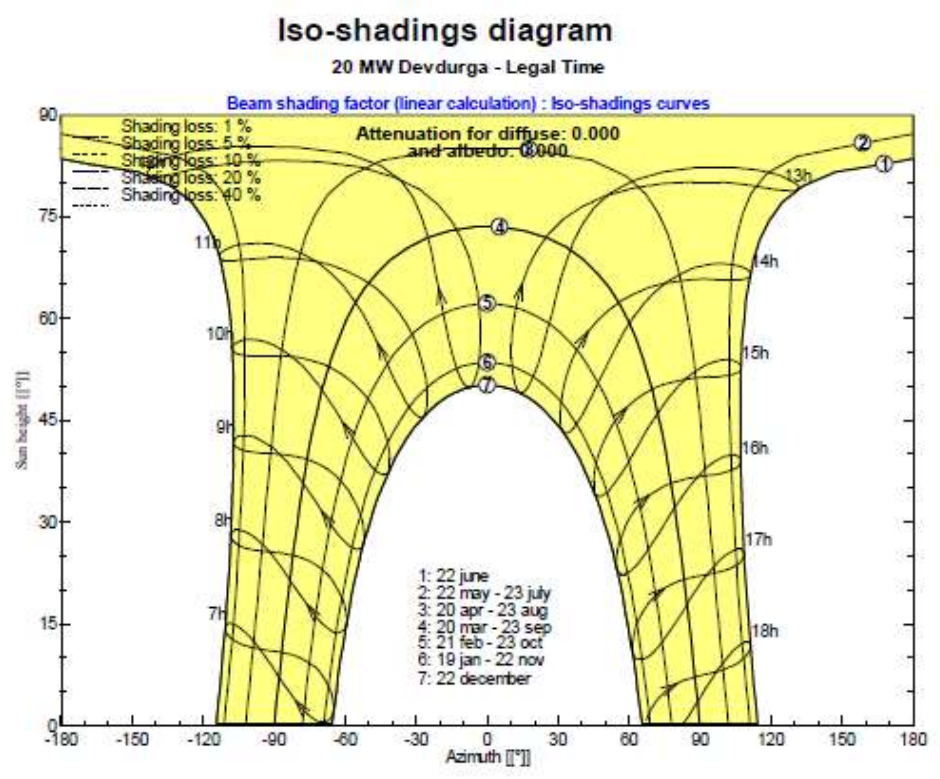

Figure 3. PV Shading Diagram using PVsyst 


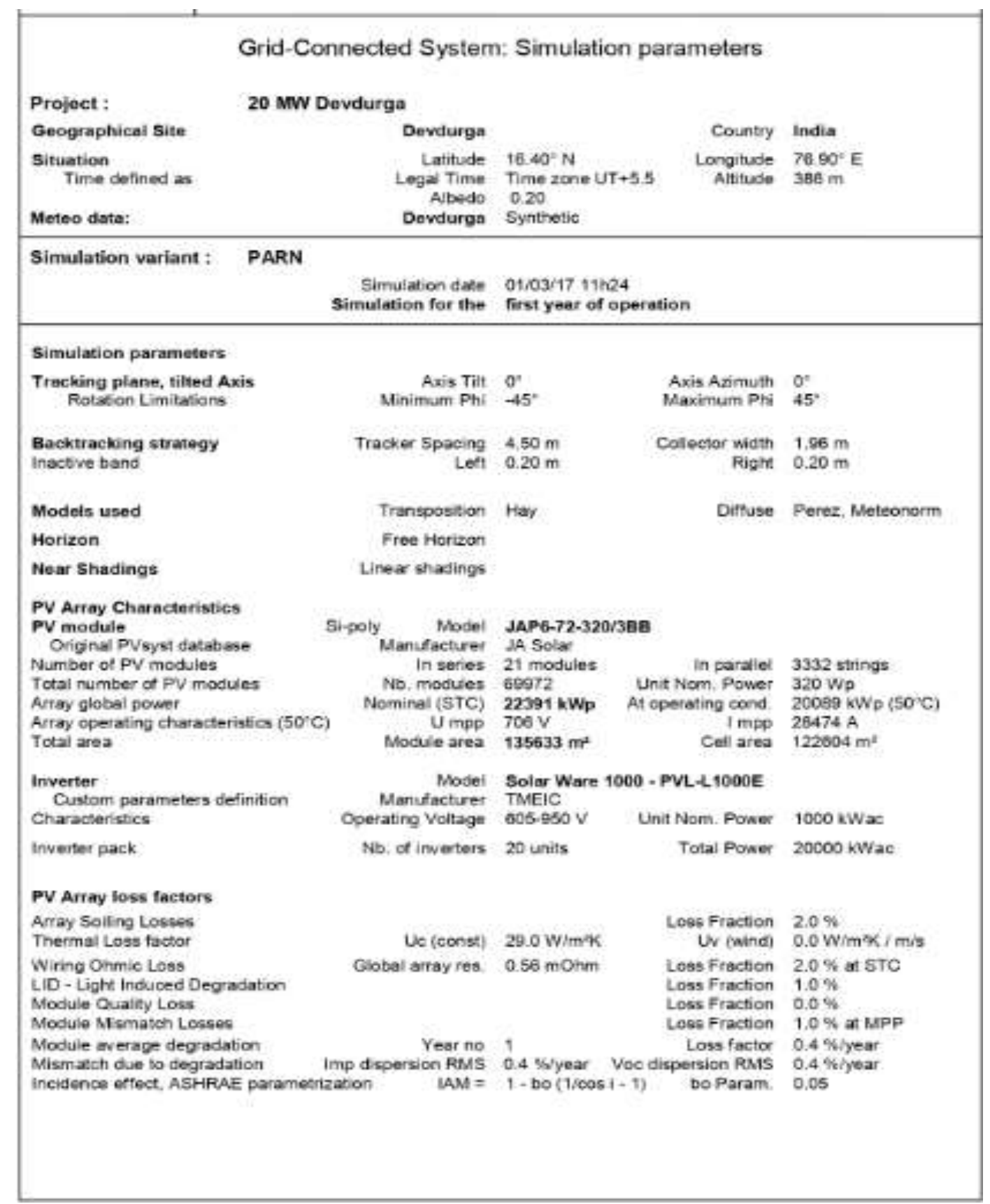

Figure 4. 20 MW Grid Connected Simulation results

Grid-Connected System: Simulation parameters (continued)

\begin{tabular}{|c|c|c|c|c|}
\hline \multicolumn{5}{|l|}{ System loss factors } \\
\hline$A C$ wire loss invertec to transfo & Inverter voltage & $418 \mathrm{Vact} i$ & & \\
\hline & Wires $3 \times 200000 \mathrm{~mm}^{2}$ & $157 \mathrm{~m}$ & Loss Fraction & $1.9 \%$ at STC \\
\hline External transformer & Iron loss (24H connexion) & $21922 \mathrm{~W}$ & Loss Fraction & $0,1 \%$ at STC \\
\hline Unavailability of the syctem & 18 days. 3 perio & & Time fraction & $0.5 \%$ \\
\hline
\end{tabular}

Figure 5. System loss factors 
Normalized productions (per installed kWp): Nominal power $22391 \mathrm{kWp}$

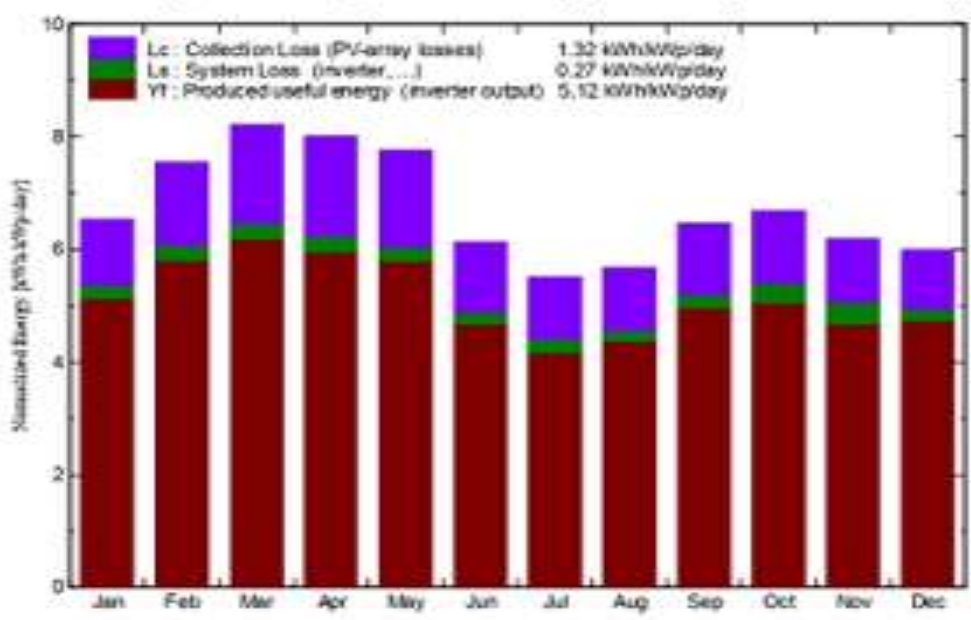

Performance Ratio PR

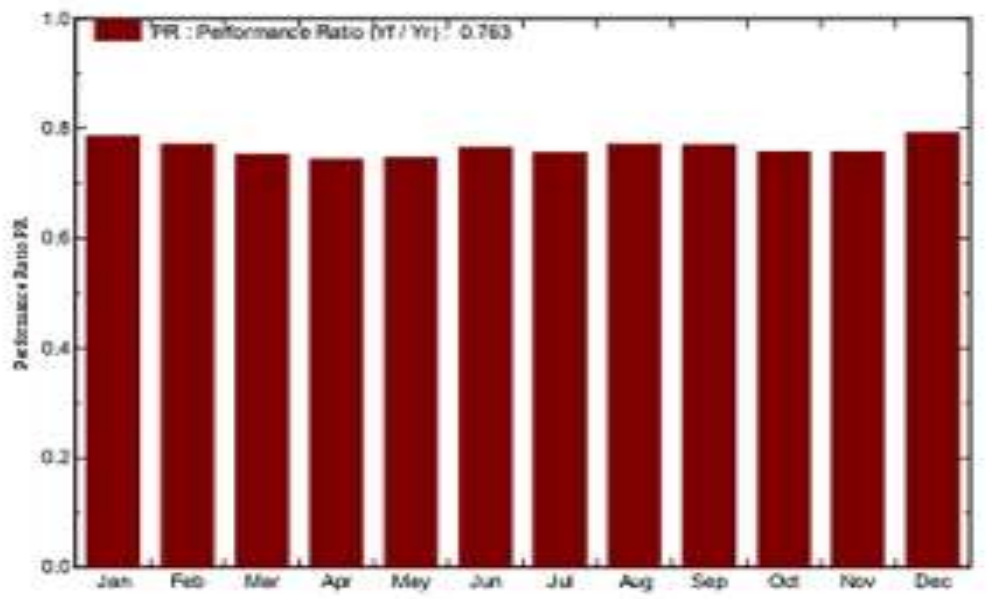

Figure 6. Yearly Irradiance

\begin{tabular}{|c|c|c|c|c|c|c|c|c|c|}
\hline & & $\begin{array}{l}\text { GobHor } \\
\text { kWh/m }\end{array}$ & $\begin{array}{c}T \text { Amb } \\
{ }^{\circ} \mathrm{C}\end{array}$ & $\begin{array}{l}\text { Globine } \\
\text { kWhime }\end{array}$ & $\begin{array}{l}\text { GlobEf } \\
\text { KWh'm } m^{x}\end{array}$ & $\begin{array}{c}\text { EArray } \\
\text { MWh }\end{array}$ & $\begin{array}{l}\text { E_Grid } \\
\text { MWh }\end{array}$ & $\begin{array}{c}\text { EHArrR } \\
\text { \&s }\end{array}$ & $\begin{array}{c}\text { EIISysR } \\
\%\end{array}$ \\
\hline Jansary & & 1590 & 2450 & 202.5 & 1895 & 3729 & 3564 & 1357 & 12.97 \\
\hline February & & 1650 & 2720 & 2110 & 1980 & 3813 & 3642 & 13.32 & 12.72 \\
\hline March & & 201.0 & 30.20 & 254.4 & 238.9 & 4496 & 4291 & 13.03 & 12.43 \\
\hline April & & 1960 & 3260 & 2404 & 2248 & 4193 & 4005 & 1286 & 12.28 \\
\hline May & & 197.0 & 3270 & 240.4 & 2246 & 4203 & 4016 & 1289 & 12.32 \\
\hline Jine & & 157.0 & 29.20 & 183.8 & 1703 & 3289 & 3143 & 1320 & 12.61 \\
\hline July & & 149.0 & 2780 & 170.6 & 1575 & 3059 & 2885 & 1326 & 12.47 \\
\hline August & & 153.0 & 27.00 & 176.1 & 1622 & 3178 & 3038 & 13.31 & 12.72 \\
\hline September & & 1590 & 27.10 & 1935 & 1802 & 3494 & 3333 & 1332 & 12.70 \\
\hline October & & 169.0 & 26.70 & 206.9 & 193.3 & 3748 & 3504 & 13.36 & 12.49 \\
\hline November & & 148.0 & 25.10 & 185.6 & 1738 & 3403 & 3146 & 13.52 & 12.50 \\
\hline December & & 1470 & 2359 & 1855 & 173.0 & 3436 & 3285 & 1366 & 13.06 \\
\hline Year & & 2000.0 & 2780 & 2450.6 & 2286.3 & 44052 & 41854 & 13.25 & 12.59 \\
\hline \multirow[t]{4}{*}{ Legends: } & Globliat & \multicolumn{3}{|c|}{ Horizontal global inradason } & & EAvray & \multicolumn{3}{|c|}{ Effecove energy at the output of the array } \\
\hline & TAmb & \multicolumn{3}{|c|}{ Ambient Temperahue } & & E_Gind & \multicolumn{3}{|c|}{ Energy injected into grid } \\
\hline & Glablne & \multicolumn{3}{|c|}{ Global incident in coll plane } & & EreArrR & \multicolumn{3}{|c|}{ Effic. Eout array $/$ rough area } \\
\hline & GlobEff & \multicolumn{4}{|c|}{ Effective Gobal, corr. for LAM and shadings } & EfSysR & \multicolumn{3}{|c|}{ Effic. Eaus system / rough area } \\
\hline
\end{tabular}

Figure 7. Yearly generation output using PVSyst 


\begin{tabular}{|c|c|c|c|c|}
\hline Main system parameters & System type & Grid-Connected & & \\
\hline Noar Shadings & Linear shadings & & & \\
\hline PV Field Orientation & tracking, tilted axis, Axis Tilt & $0^{*}$ & Axis Azimuth & $0^{*}$ \\
\hline PV modules & Model & JAP6-72-320/3BB & Pnom & $320 \mathrm{Wp}$ \\
\hline PV Array & $\mathrm{Nb}$, of modules & 69972 & Pnom total & $22391 \mathrm{kWp}$ \\
\hline Inverter & Madel & Sclar Ware 1000. & PVL-L.1000E & $1000 \mathrm{~kW}$ ac \\
\hline Inverter pack & $\mathrm{Nb}$. of units & 20.0 & Pnom total & $20000 \mathrm{~kW}$ ac \\
\hline User's needs & Unlimited load (grid) & & & \\
\hline
\end{tabular}

Loss diagram over the whole year

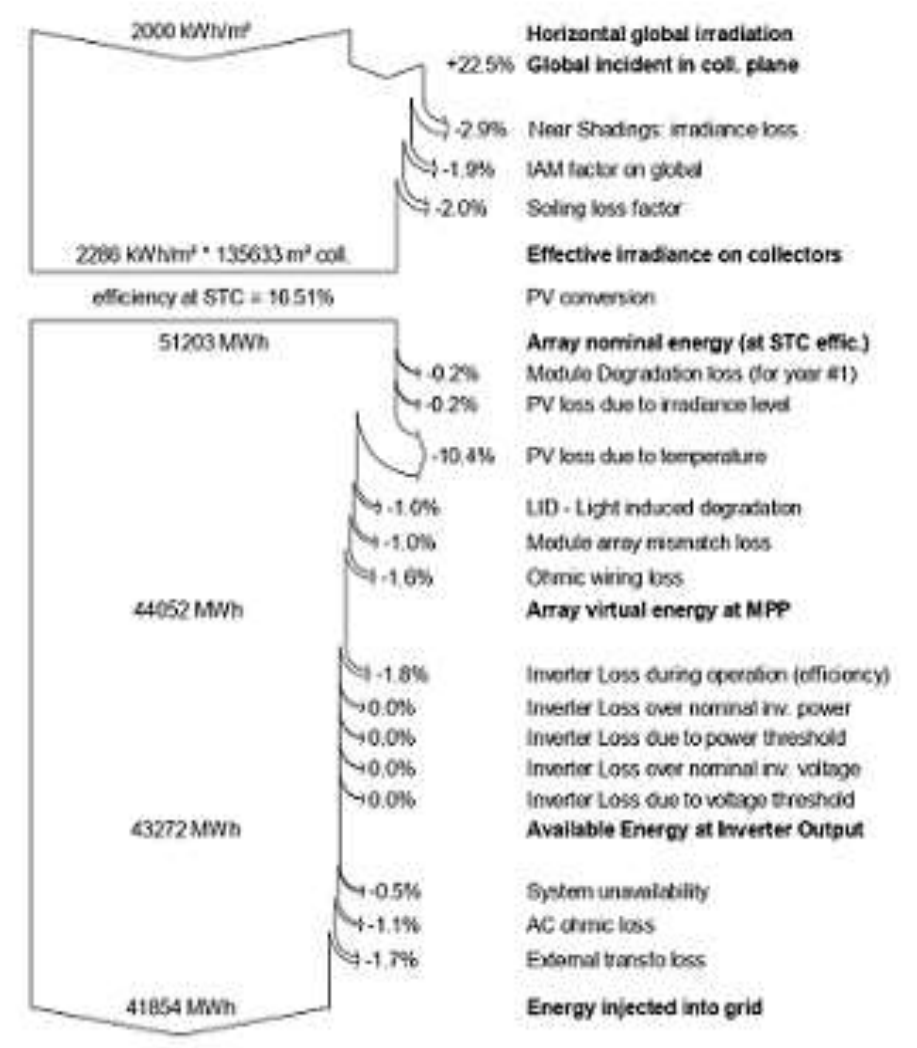

Figure 8. Annual Loss diagram of $20 \mathrm{MW}$ plant using PVsyst

\section{CONCLUSION}

To validate the design of the PV Grid tied system, it is difficult to coordinate the theoretical calculations for real data obtained from geographical positions. The PV syst has given authentic results for the genuine data received from maps. This must be done so as to dissect and identify potential causes that assists in accomplishment of the photovoltaic system. This investigation has demonstrated the constancy of the PVsyst in the estimating the size of the components solar integrated grid. A detailed analysis of $20 \mathrm{MW}$ grid tied solar power plant at Devdurga, Karnataka has been done using PVsyst software. The performance of the plant has been observed on annual basis. The analysis gives peak output power of 22.4MW and the minimum power of 80.1 MW. The maximum energy output of $4291 \mathrm{MWh}$ is perceived in the month of March and the minimum energy output is in $2886 \mathrm{MWh}$ in the month of July.

Therefore, the investigation has affirmed the reliability of the PVsyst programming in estimating and in planning of photovoltaic application. The issues which impact the execution of based solar powered modules are a result of the operational temperature of the photovoltaic cells. To lessen the misfortunes in existing innovation, low wind speed and high temperature of PV module may give vital outcomes. To accomplish the correct measuring of the network associated project, it is necessary to correlate the hypothetical calculations through logical estimations utilizing PVsyst and afterward making comparison analysis with real time generation. 


\section{OREFERENCES}

[1] S. Sarip, et. al. "Hybrid Renewable Energy Power System Model Based on Electrification Requirements of One Fathom Bank Malaysia", Indonesian Journal of Electrical Engineering and Computer Science, Vol. 12, No. 2, pp. 513 520, November 2018.

[2] S. M Rompicherla."Solar Energy: The Future". International Journal of Engineering Trends and Technology (IJETT). Vol. 4, No (6), pp2513-2517, June 2013.

[3] Celik, A.N. Acikgoz, N. "Modelling and experimental verification of the operating current of mono -crystalline photovoltaic modules using four-and five parameter models." Applied Energy. Vol. 84, pp1 - 15, 2007.

[4] Grover A, et. Al., Study of Different Simulation Softwares For Optimization And Economic Analysis Of Photovoltaic System. International Journal of Advanced Research (IJAR), vol, 7(5), pp1163-1170, May 2019.

[5] Grover A, et. al "Future Aspects of Renewable Energy Development in India", International Journal of Engineering Technology Science and Research, IJETSR, Vol. 4, Issue 9, September 2017.

[6] Taghvaee M.H. et al., "A current and future study on non-isolated DC-DC converters for photovoltaic applications" Renewable and Sustainable Energy Reviews, Vol, 17, 216-227, 2013.

[7] Umar M.W et al. "State-space averaged modeling and transfer function derivation of DC-DC boost converter for highbrightness led lighting applications”, TELKOMNIKA (Telecommunication, Computing, Electronics and Control), Vol, 17(2), pp.1006-1013, 2019.

[8] Hassane Ben Slimane, Ben Moussa Dennai, Helmaoui Abderrachid. Theoretical Study of Multiple Solar Cells System as a Function of Temperature, TELKOMNIKA Indonesian Journal of Electrical Engineering. Vol, 12(7): 4928 4933, 2014. DOI: 10.11591/telkomnika.v12i7.5363.

[9] Chattopadhyay S., et. al "Visual Degradation in Field-Aged Crystalline Silicon PV Modules in India and Correlation with Electrical Degradation," IEEE Journal of photovoltaics, vol. 4, pp. 1470-1476, 2014.

[10] B. K. Perera, P. Ciufo, S. Perera, "Point of Common Coupling (PCC) voltage control of a grid-connected solar Photovoltaic (PV) system," 39th Annual Conference of the IEEE Industrial Electronics Society (IECON 2013). pp.7475-7480. 2013.

[11] H. Xiao and S. Xie, "Leakage current analytical model and application in single-phase transformerless photovoltaic grid-connected inverter," IEEE Trans., vol. 52, no. 4, pp. 902-913, Nov. 2010.

[12] S. Chin, J. Gadson, and K. Nordstrom. Maximum power point tracker. Tufts University Department of Electrical Engineering and Computer Science, pp.1 -66, 2003.

[13] Y. Muñoz, J. Guerrero y A. Ospino, "Evaluation of hybrid system of renewable electricity generation a remote area of Colombia using homer software", Tecciencia, Vol. 9, No. 17, pp. 45-54, 2014.

[14] O.W. Westbrook, F.D. Collins, "Energy Model Validation for Large-Scale Photovoltaic systems." In Photovoltaic Specialists Conference (PVSC), IEEE 39t, pp.0830-0835, 2013.

[15] C. P. Kandasamy, P.Prabu, and K.Niruba, "Solar potential assessment using PVSYST software." In Green Computing, Communication and Conservation of Energy (ICGCE), 2013.

[16] Mohammad Ramadhan, Adel Naseeb, "The cost benefit analysis of implementing photovoltaic solar system in the state of Kuwait", Renewable Energy, vol, 36, pp. 1272-1276, 2011.

[17] S. Labed, E. Lorenzo, "The impact of solar radiation variability and data Discrepancies on the design of PV systems," Renewable Energy, vol, 29, pp. 1007-1022, 2004.

[18] Shalwala, R. A., and Bleijs, 1. A. M., "Impact of Grid-Connected PV systems in residential areas in Saudi Arabia," proc. of the 44th International Universities Power Engineering Conference (UPEC), (IEEE 2009), pp1-5, 2009.

[19] Ashok Kumar, N.S.Thakur, Rahul Makade, Maneesh Kumar Shivhare, "Optimization of Tilt angle for Photovoltaic Array," International Journal of Engineering Science and Technology (IJEST), Vol. 3, No.4, pp. 3153-3161, 2011.

[20] Hasimah, A. R., Khalid, M. N., and Mohammad, Y. H., "Assessment of PY cell performance under actual Malaysia operating condition," Power Engineering Conference, AUPEC, Australasian Universities, (IEEE 2009), pp1-5, 2009.

[21] Qoaider, L., and Steinbrecht, D.A cost competitive option to supply energy to off-grid agricultural communities in arid regions," Applied Energy, vol. 87.2, pp. 427-435, 2010.

[22] Bindu U Kansara, B.R. Parekh, "Modelling and simulation of distributed generation system using HOMER software," IEEE, 2011.

[23] C.P. Kandasamy, P. Prabu, K.Niruba, "Solar Potential Assessment Using PVSYST Software," 2013 International Conference on Green Computing, Communication and Conservation of Energy (ICGCE). 2013.

[24] Goura, R. "Analyzing the on-field performance of a 1-641 megawatt-grid -tied PV system in South India." International. Journal of Sustainable Energy, vol, 34, 1-9.

[25] K. S. Srikanth, "A Three Phase Multi Level Converter for Grid Connected PV System," International Journal of Power Electronics and Drive System (IJPEDS), vol 5(1), pp. 71-75, 2014

[26] Guo, Xiaoqiang \& Xu, David \& Wu, Bin, 2014. "Overview of anti-islanding US patents for grid-connected inverters," Renewable and Sustainable Energy Reviews, Elsevier, vol. 40(C), pages 311-317, 2014. 